\title{
Anti-Proliferative Properties of Terminalia sericea Burch. Ex Dc Leaf Extracts Against Caco2 and HeLa Cancer Cell Lines
}

\author{
BiYun $\mathrm{Gu}^{1,2}$, Joseph Shalom ${ }^{1,3}$, Ian E. Cock ${ }^{1,3^{*}}$
}

\section{BiYun $\mathrm{Gu}^{1,2}$ Joseph Shalom ${ }^{1,3}$, Ian E. Cock ${ }^{1,3^{*}}$}

'School of Natural Sciences, Nathan Campus, Griffith University, 170 Kessels Rd, Nathan, Queensland 4111, AUSTRALIA

${ }^{2} S$ chool of Pharmacy,

Nanjing University of Chinese Medicine, Nanjing, CHINA.

${ }^{3}$ Environmental Futures Research Institute, Nathan Campus, Griffith University, 170 Kessels Rd, Nathan, Queensland 4111, AUSTRALIA

\section{Correspondence}

\section{Ian E. Cock}

School of Natural Sciences, Nathan Campus, Griffith University, 170 Kessels Rd, Nathan, Queensland 4111, AUSTRALIA \& Environmental Futures Research Institute, Nathan Campus, Griffith University, 170 Kessels Rd, Nathan, Queensland 4111, AUSTRALIA

Phone no : 61-7-37357637

E-mail: I.Cock@griffith.edu.au

History

- Submission Date: 07-08-2017;

- Review completed: 31-08-2017:

- Accepted Date: 02-11-2017

\section{DOI : 10.5530/pj.2018.3.67}

Article Available online

http://www.phcogj.com/v10/i3

\section{Copyright}

(C) 2018 Phcog.Net. This is an openaccess article distributed under the terms of the Creative Commons Attribution 4.0 International license.

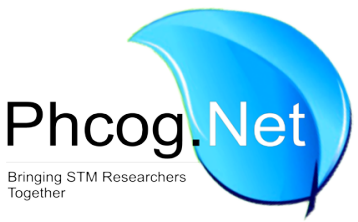

\begin{abstract}
Introduction: Terminalia spp. are characterised by their high levels of antioxidant phytochemicals and several species have anticancer activity. This study examines the anti-proliferative activity of T. sericea leaf extracts against $\mathrm{Caco} 2$ and HeLa carcinoma cell proliferation. Methods: Solvent extracts were prepared from $T$. sericea leaves and their antioxidant capacities were determined by the DPPH free radical scavenging assay. Anti-proliferative activities against Caco2 and HeLa cancer cells were determined by an MTS based cell proliferation assay. Toxicity was determined using the Artemia franciscana nauplii bioassay. Results: The methanolic and aqueous $T$. sericea leaf extracts displayed high antioxidant capacities (equivalent to 150 and $340 \mathrm{mg}$ of ascorbic acid per gram of plant material extracted respectively). In contrast, the ethyl acetate, chloroform and hexane extracts had relatively low antioxidant contents $(\leq 5 \mathrm{mg}$ of ascorbic acid equivalents per gram of plant material extracted). The antioxidant contents of the T. sericea leaf extracts correlated with the ability of the extracts to inhibit proliferation of $\mathrm{Caco} 2$ and HeLa cancer cell lines. The high antioxidant methanolic and aqueous extracts were potent inhibitors of cell proliferation, with $I_{50}$ values $120-1400 \mu \mathrm{g} / \mathrm{mL}$. The aqueous $T$. sericea leaf extract was particularly effective, with ${ }^{1} C_{50}$ values of 528 and $120 \mu \mathrm{g} / \mathrm{mL}$ against Caco2 and HeLa cells respectively. The methanolic extract also displayed good, albeit substantially less potent, antiproliferative activity against HeLa cells, with an $\mathrm{IC}_{50}$ of $1358 \mu \mathrm{g} / \mathrm{mL}$. In contrast, the lower antioxidant content extracts generally did not inhibit cancer cell proliferation. Cell imaging studies detected morphological features consistent with apoptosis in Caco2 cells exposed to sub-lethal concentrations of the methanolic and aqueous T. sericea leaf extracts, indicating that these extracts are functioning by cytotoxic mechanisms. The aqueous T. sericea leaf extract displayed low to moderate toxicity in the Artemia franciscana bioassay, with an $\mathrm{LC}_{50}$ value of $737 \mu \mathrm{g} / \mathrm{mL}$. All other extracts were nontoxic. Conclusion: The antiproliferative activity and low toxicity of the T. sericea methanolic and aqueous leaf extracts extracts against HeLa and $\mathrm{Caco} 2$ cancer cell lines indicates their potential in the treatment and prevention of some cancers.
\end{abstract}

Key words: Combretaceae, Silver Cluster Leaf, Anticancer Activity, Antiproliferative Activity, Antioxidant Capacity, Apoptosis, DPPH.

\section{INTRODUCTION}

Epidemiological studies have shown that a diet rich in antioxidants is associated with a decreased incidence of chronic diseases. ${ }^{1}$ High antioxidant levels have also been shown to act as a preventative against the development of degenerative diseases such as cancer, ${ }^{2}$ cardiovascular diseases, ${ }^{3}$ neural degeneration, ${ }^{4}$ diabetes and obesity. ${ }^{5}$ Phenolic phytochemicals are generally strong antioxidants. ${ }^{6}$ Their primary action involves the protection of cell constituents against oxidative damage through the scavenging of free radicals, thereby averting their deleterious effects on nucleic acids, proteins, and lipids in cells. ${ }^{6}$ Phenolics interact directly with receptors or enzymes involved in signal transduction, ${ }^{7}$ indicating that they play specific roles in human physiology via modulation of the cellular redox state. Common plant phenolic compounds include flavonoids, tannins, anthocyanins, and gallic acid.
The relationship between cellular redox state and cancer progression has been particularly well studied. The induction of cellular oxidative stress has been linked with several types of cancer. ${ }^{8,9}$ Thus it is possible that high antioxidant contents of many plants may inhibit cancer formation and/or progression. Studies into the antioxidant/pro-oxidant effects of extracts from various plant species have demonstrated that the ability of a plant extract to exert antioxidant activity depends on multiple factors. Aloe vera antioxidant components for example may function as either antioxidants or a pro-oxidants, with their action being dependent upon their concentration. ${ }^{10}$ The Aloe vera anthraquinone aloe emodin exerts antioxidant behaviour at lower concentrations, yet acts as a pro-oxidant at high concentrations. In contrast, a different Aloe vera anthraquinone (aloin) has an antioxidant effect at

Cite this article: Gu B, Shalom J, Cock IE. Anti-Proliferative Properties of Terminalia Sericea Burch. Ex Dc Leaf Extracts Against Caco2 and Hela Cancer Cell Lines. Pharmacog J. 2018;10(2):40815 
higher concentrations, yet a pro-oxidant effect at low concentrations. Thus, Aloe vera extracts and components may act as either antioxidants or as pro-oxidants, dependent on differing levels of the various constituents, and on their ratios. Thus, although many plant species have very high antioxidant contents, it is possible that the individual components may act as either antioxidants or as pro-oxidants and thus may also be effective in the treatment of cancer, as well as in its prevention at different concentrations.

Similar pro-oxidant effects have been reported for other antioxidant phytochemicals including flavonoids ${ }^{11}$ and tannins. ${ }^{12}$ Furthermore, the presence of transition metal ions such as copper or iron in an extract can further enhance the conversion of the antioxidant to the pro-oxidant state. $^{13,14}$ The pro-oxidant/antioxidant effect of plant extracts is due to a balance between the free radical scavenging activities and reducing power of their phytochemical components. This can be explained using the antioxidant vitamin ascorbic acid as an example. Although ascorbic acid has well characterised antioxidant bioactivities, it acts as a pro-oxidant at high concentrations. ${ }^{15}$ This is due to the greater reducing power of ascorbic acid compared to its free radical scavenging activity. In the presence of transition metal ions, ascorbic acid will function as a reducing agent, reducing the metal ions. In this process, it is converted to a pro-oxidant. Therefore, high dietary intake of ascorbic acid (or other antioxidants) in individuals with high iron levels (e.g. premature infants) may result in unexpected health effects due to the induction of oxidative damage to susceptible biomolecules. ${ }^{16,17,18}$

Plants of the genus Terminalia (family Combretaceae) are characterised by their high antioxidant contents. ${ }^{19}$ It has previously been postulated that these high antioxidant contents may provide them with therapeutic effects. Furthermore, several individual Terminalia spp., (and traditional medicine combinations containing Terminalia spp.) have been reported to have potent anticancer properties. The Ayurvedic medicine Triphala (which contains Terminalia belliricia (Gawrtn.) Roxb. and Terminalia chebula (Retz.) Lyons) has cytotoxic effects against thymic lymphoma cells ${ }^{20,21}$ human breast cancer cell lines. ${ }^{21,22}$ human prostate cancer cell lines and human pancreatic cancer cell lines. ${ }^{23}$ Conversely, the cytotoxic effects of Triphala are negligible in normal cell lines..$^{20,21} T$. belliricia extracts have also demonstrated growth inhibitory effects towards human A549 lung cancer cell lines and HepG2 hepatocarcinoma cell lines without the presence of the other plant components present in Triphala. ${ }^{24}$ T. belliricia extracts also have synergistic effects with conventional anticancer chemotherapeutics, enhancing the cytotoxic activity of cisplatin and doxorubicin towards the cancer cell lines, indicating their potential as synergistic cancer chemotherapeutic agents. Similarly, the Australian species Terminalia ferdinandiana Exell. has broad spectrum anti-proliferative activity against a panel of cancer cell lines. ${ }^{25}$ The proliferation of normal cell lines was also inhibited in that study. The extract activated caspase- 7 and caspase- 9 as well as poly (ADP-ribose) polymerase (PARP), indicating that apoptosis induction is via an intrinsic pathway. Extracts prepared from the leaves of two other Australian Terminalia spp. (T. carpentariae and T. grandiflora) were also recently reported to be good inhibitors of $\mathrm{Caco} 2$ and HeLa cell proliferation. ${ }^{26}$ That study identified 3 lanostane and 2 pentacyclic triterpenoids in the extracts and postulated that they may contribute to this activity. Despite these previous studies, limited information is available on the anticancer activity of other Terminalia spp. This study screened the Southern African species Terminalia sericea C.T. White for the ability to inhibit proliferation of Caco2 colorectal and HeLa cervical cancer cell lines.

\section{MATERIALS AND METHODS}

\section{Plant source and extraction}

The Terminalia sericea Burch. Ex DC. Leaves used in this study were supplied by Professor Sandy van Vuuren of Witwatersrand University,
South Africa and were sourced from the Walter Sisulu Botanical Gardens in Johannesburg, South Africa. The plant materials were identified by Andrew Hankey, chief botanist at the Walter Sisulu Botanical Gardens in Johannesburg, South Africa. Voucher specimens are stored in the School of Natural Sciences, Griffith University, Australia. All plant material was thoroughly air dried and ground into a coarse powder. The dried plant material was stored at $-30^{\circ} \mathrm{C}$ until use. Individual $1 \mathrm{~g}$ quantities of the powdered T. sericea were weighed into separate tubes and $50 \mathrm{~mL}$ of methanol, deionised water, ethyl acetate, chloroform or hexane were added. All solvents were obtained from Ajax Chemicals, Australia and were AR grade. The ground T. sericea leaf material was extracted in each solvent for $24 \mathrm{~h}$ at $4{ }^{\circ} \mathrm{C}$ with gentle shaking. The extracts were filtered through filter paper (Whatman No. 54) under vacuum. The solvent extracts were dried in a vacuum oven and the aqueous extract was dried by freeze drying. The resultant dry extract was weighed and redissolved in $10 \mathrm{~mL}$ deionised water (containing $1 \% \mathrm{DMSO}$ ).

\section{Qualitative phytochemical studies}

Phytochemical analysis of the extracts for the presence of saponins, phenolic compounds, flavonoids, polysteroids, triterpenoids, cardiac glycosides, anthraquinones, tannins and alkaloids was conducted by previously described assays..$^{27,28}$

\section{Antioxidant capacity}

The antioxidant capacity of each sample was assessed using the DPPH free radical scavenging method ${ }^{29}$ with modifications. Briefly, DPPH solution was prepared fresh each day as a $400 \mu \mathrm{M}$ solution by dissolving $\mathrm{DPPH}$ (Sigma) in AR grade methanol (Ajax, Australia). The initial absorbance of the DPPH solution was measured at $515 \mathrm{~nm}$ using a Molecular Devices, Spectra Max M3 plate reader and did not change significantly throughout the assay period. A $2 \mathrm{~mL}$ aliquot of each extract was evaporated and the residue resuspended in $2 \mathrm{~mL}$ of methanol. Each extract was added to a 96-well plate in $5,10,25,50,75 \mu \mathrm{L}$ volumes in triplicate. Methanol was added to each well to give a volume of $225 \mu \mathrm{L}$. A volume of $75 \mu \mathrm{L}$ of the fresh DPPH solution was added to each well for a total reaction volume of $300 \mu \mathrm{L}$. A blank of each extract concentration, methanol solvent, and DPPH was also performed in triplicate. Ascorbic acid was prepared fresh and examined across the range 0-25 $\mu \mathrm{g}$ per well as a reference and the absorbances were recorded at $515 \mathrm{~nm}$. All tests were performed in triplicate and triplicate controls were included on each plate. The antioxidant capacity based on DPPH free radical scavenging ability was determined for each extract and expressed as $\mu \mathrm{g}$ ascorbic acid equivalents per gram of original plant material extracted.

\section{Screen for anticancer bioactivity}

\section{Cancer cell lines}

The Caco2 and HeLa carcinoma cell lines used in this study were obtained from American Type Culture Collection (Rockville, USA). The cells were cultured in Roswell Park Memorial Institute (RPMI) 1640 medium (Life Technologies), supplemented with $20 \mathrm{mM}$ HEPES, $10 \mathrm{mM}$ sodium bicarbonate, $50 \mu \mathrm{g} / \mathrm{mL}$ streptomycin, $50 \mathrm{IU} / \mathrm{mL}$ penicillin, $2 \mathrm{mM}$ glutamine and $10 \%$ foetal calf serum (Life Technologies). The cells were maintained as monolayers in $75 \mathrm{~mL}$ flasks at $37^{\circ} \mathrm{C}, 5 \% \mathrm{CO}_{2}$ in a humidified atmosphere until approximately $80 \%$ confluent.

\section{Evaluation of cancer cell antiproliferative activity}

Antiproliferative activity of the extracts was assessed as previously described. ${ }^{30}$ Briefly, $1 \mathrm{~mL}$ of trypsin (Sigma) was added to the culture flasks and incubated at $37^{\circ} \mathrm{C}, 5 \% \mathrm{CO}_{2}$ for $15 \mathrm{~min}$ to dislodge the cancer cells. The cell suspensions were then transferred to a $10 \mathrm{~mL}$ centrifuge tube and sedimented by centrifugation. The supernatant was discarded and the cells were resuspended in $9 \mathrm{~mL}$ of fresh media. Aliquots of the resuspended cells $(70 \mu \mathrm{L}$, containing approximately 5000 cells) were 
added to the wells of a 96 well plate. A volume of $30 \mu \mathrm{L}$ of the test extracts or cell media (for the negative control) was added to individual wells and the plates were incubated at $37{ }^{\circ} \mathrm{C}, 5 \% \mathrm{CO}_{2}$ for $12 \mathrm{~h}$ in a humidified atmosphere. A volume of $20 \mu \mathrm{L}$ of Cell Titre 96 Aqueous One solution (Promega) was subsequently added to each well and the plates were incubated for a further $3 \mathrm{~h}$. Absorbances were recorded at $490 \mathrm{~nm}$ using a Molecular Devices, Spectra Max M3 plate reader. All tests were performed in at least triplicate and triplicate controls were included on each plate. The antiproliferative activity of each test was calculated as a percentage of the negative control using the following formula:

$$
\text { Proliferation }(\% \text { untreated control })=\left(\mathrm{A}_{\mathrm{ct}} / \mathrm{A}_{\mathrm{cc}}\right) \times 100
$$

$\mathrm{A}_{\mathrm{ct}}$ is the corrected absorbance for the test extract (calculated by subtracting the absorbance of the test extract in media without cells from the extract cell test combination) and $A_{c c}$ is the corrected untreated control (calculated by subtracting the absorbance of the untreated control in media without cells from the untreated cell media combination).

\section{Cell imaging studies}

Cell morphological changes were measured using bright field microscopic imaging without staining. Briefly, Caco2 cells were seeded into individual wells of a 96 well plate at a density of $5 \times 10^{3}$ cells / $100 \mu \mathrm{L}$ in a 96 well plate. Cells were allowed to adhere overnight. Selected T. sericea extracts were added to the wells at predetermined concentrations (previously determined to be the highest concentration which induced $<10 \%$ change in proliferation compared to the untreated control). Cells were incubated for $24 \mathrm{~h}$ at $37^{\circ} \mathrm{C}$ in a humidified $5 \% \mathrm{CO}_{2}, 95 \%$ air atmosphere. Each assay was performed in triplicate and the cell morphology was qualitatively appraised after $24 \mathrm{~h}$ treatment by using an inverted phase microscope with camera (Olympus IX70) with an optical zoom of $20 \mathrm{X}$. The images were captured via computer and analysed to scale.

\section{Toxicity screening}

\section{Reference toxin for toxicity screening}

Potassium dichromate $\left(\mathrm{K}_{2} \mathrm{Cr}_{2} \mathrm{O}_{7}\right)$ (AR grade, Chem-Supply, Australia) was prepared as a $1.6 \mathrm{mg} / \mathrm{mL}$ solution in distilled water and was serially diluted in artificial seawater for use in the Artemia franciscana nauplii bioassay.

\section{Artemia franciscana nauplii toxicity screening}

Toxicity was tested using a modified Artemia franciscana nauplii lethality assay. ${ }^{31-34}$ Briefly, $400 \mu \mathrm{L}$ of seawater containing approximately 53 (mean 53.1, $\mathrm{n}=125, \mathrm{SD} 12.3$ ) A. franciscana nauplii were added to wells of a 48 well plate and immediately used for bioassay. A volume of $400 \mu \mathrm{L}$ of diluted plant extracts or the reference toxin were transferred to the wells and incubated at $25 \pm 1^{\circ} \mathrm{C}$ under artificial light (1000 Lux). A negative control ( $400 \mu \mathrm{L}$ seawater) was run in triplicate for each plate. All treatments were performed in at least triplicate. The wells were checked at regular intervals and the number of dead counted. The nauplii were considered dead if no movement of the appendages was observed within 10 seconds. After $24 \mathrm{~h}$, all nauplii were sacrificed and counted to determine the total $\%$ mortality per well. The $\mathrm{LC}_{50}$ with $95 \%$ confidence limits for each treatment was calculated using probit analysis.

\section{Statistical analysis}

Data are expressed as the mean \pm SEM of at least three independent experiments. One way ANOVA was used to calculate statistical significance between control and treated groups with a $P$ value $<0.01$ considered to be statistically significant.

\section{RESULTS}

\section{Liquid extraction yields and qualitative phytochemical screening}

Extraction of $1 \mathrm{~g}$ of the dried T. sericea powder with solvents of varying polarity yielded dried plant extracts ranging from $38 \mathrm{mg}$ (ethyl acetate T. sericea leaf extract) to $220 \mathrm{mg}$ (methanolic T. sericea leaf extract) (Table 1). The higher polarity methanol and water solvents generally extracted relatively high yields of plant material whilst the mid to lower polarity solvents extracted considerably less material. The dried extracts were resuspended in $10 \mathrm{~mL}$ of deionised water (containing $1 \%$ DMSO), resulting in the extract concentrations shown in Table 1.

Qualitative phytochemical studies (Table 1) showed that methanol and water extracted the widest range of phytochemicals. Both showed moderate to high levels of phenolics (both water soluble and insoluble

Table 1: The mass of dried extracted material, the concentration after resuspension in deionised water, qualitative phytochemical screenings and antioxidant capacities of the $T$. sericea extracts.

\begin{tabular}{|c|c|c|c|c|c|c|c|c|c|c|c|c|c|c|c|c|}
\hline 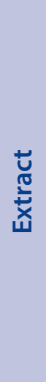 & 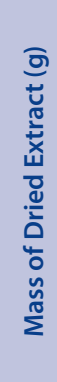 & 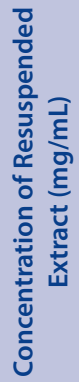 & 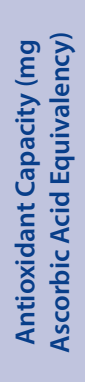 & 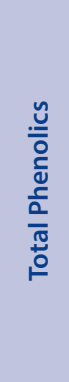 & 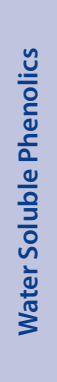 & 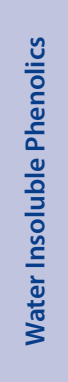 & 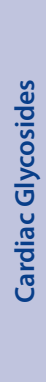 & 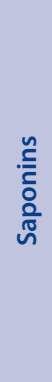 & 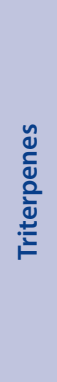 & 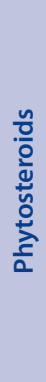 & 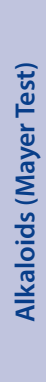 & 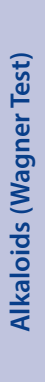 & $\begin{array}{l}\frac{n}{0} \\
\frac{0}{0} \\
\frac{0}{0} \\
\frac{\pi}{4}\end{array}$ & 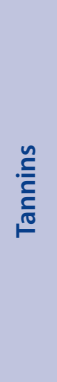 & 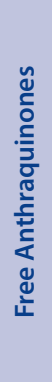 & 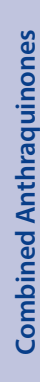 \\
\hline $\mathrm{M}$ & 220 & 22 & 150 & +++ & ++ & ++ & - & + & ++ & - & - & - & +++ & ++ & - & - \\
\hline $\mathrm{W}$ & 210 & 21 & 340 & +++ & ++ & +++ & - & + & ++ & - & - & - & +++ & ++ & - & - \\
\hline $\mathrm{E}$ & 39 & 4 & 22 & ++ & + & + & - & - & + & - & - & - & + & - & - & - \\
\hline C & 117 & 12 & 5 & - & - & - & - & - & - & - & - & - & ++ & - & - & - \\
\hline $\mathrm{H}$ & 38 & 4 & 0.4 & - & - & - & - & - & - & - & - & - & + & - & - & - \\
\hline
\end{tabular}

+++ indicates a large response; ++ indicates a moderate response; + indicates a minor response; - indicates no response in the assay; $M=$ methanolic T. sericea extract; $\mathrm{W}=$ aqueous T. sericea extract; $\mathrm{E}=$ ethyl acetate T. sericea extract; $\mathrm{C}=$ chloroform T. sericea extract; $\mathrm{H}=$ hexane $T$. sericea extract. Antioxidant capacity was determined by DPPH reduction and is expressed as $\mathrm{mg}$ of ascorbic acid equivalents per gram of dried plant material extracted. 
phenolics), flavonoids, tannins and triterpenoids as well as low levels of saponins. Ethyl acetate extracted similar classes of compounds, albeit at lower levels. The chloroform and hexane extracts were much less complex, with only low to moderate relative abundances of flavonoids detected in both extracts. Phytosterols, alkaloids, cardiac glycosides and anthraquinones were not detected in any extract.

\section{Antioxidant content}

Antioxidant capacity (expressed as ascorbic acid equivalents) for the T. sericea extracts are shown in Table 1 . The antioxidant capacity ranged from a low of $0.4 \mathrm{mg}$ ascorbic acid equivalents per gram of dried plant material extracted (T. sericea hexane extract) to a high of $340 \mathrm{mg}$ ascorbic acid equivalents per gram of dried plant material extracted (aqueous T. sericea extract). The T. sericea methanol extract also had a high antioxidant capacity of $150 \mathrm{mg}$ ascorbic acid equivalents per gram of dried plant material extracted. The ethyl acetate extract had a moderate antioxidant capacity (22 mg ascorbic acid equivalents).

\section{Antiproliferative activity}

Aliquots of each extract were tested for the ability to inhibit proliferation of Caco2 (Figure 1) and HeLa (Figure 2) cell lines. Three of the T. sericea leaf extracts displayed significant $(\mathrm{p}<0.01)$ antiproliferative effects against the Caco 2 cells. The aqueous extract was the most potent inhibitor, with proliferation inhibited by approximately $83 \%$ compared to the negative control cell proliferation. Inhibition of proliferation by the aqueous extract was dose dependent, with the level of inhibitory activity decreasing at lower concentrations (Table 2). The methanolic and ethyl acetate extracts also significantly inhibited proliferation, albeit by substantially lower levels ( 28 and $36 \%$ inhibition of proliferation respectively). The dose dependent proliferative activity of these extracts were not evaluated in this study. The chloroform and hexane extracts were completely devoid of antiproliferative activity against $\mathrm{Caco} 2$ cells.

The extracts were similarly effective at inhibiting HeLa cancer cell proliferation. Three of the T. sericea leaf extracts had significant $(\mathrm{p}<0.01)$ antiproliferative effects against the HeLa cell line. As seen for the Caco2 cells, the methanolic, aqueous and ethyl acetate extracts inhibited HeLa carcinoma cell growth significantly $(\mathrm{p}<0.01)$. The aqueous extract was the most potent inhibitor, with proliferation inhibited by approximately $96 \%$ compared to the negative control cell proliferation. The methanolic extract was also had potent antiproliferative effects, inhibiting HeLa cell proliferation by approximately $62 \%$ compared to the negative control cell proliferation. Inhibition of proliferation by the aqueous and methanolic extracts was dose dependent, with the level of inhibitory activity decreasing at lower concentrations (Table 2). The ethyl acetate extracts also inhibited proliferation, albeit by only approximately $12 \%$ compared to the negative control cell proliferation. The chloroform and hexane extracts were completely devoid of antiproliferative activity against HeLa cells.

The antiproliferative efficacy was further quantified by determining the $\mathrm{IC}_{50}$ values for each extract which inhibited cell proliferation against each cell line (Table 2). The aqueous extracts were particularly effective at inhibiting both Caco 2 and HeLa cancer cell proliferation at low concentrations, with $\mathrm{IC}_{50}$ values of approximately $500 \mu \mathrm{g} / \mathrm{mL}$ and $100 \mu \mathrm{g} / \mathrm{mL}$ respectively. The methanolic $T$. sericea extract was also a moderate to good inhibitor of HeLa, with an $\mathrm{IC}_{50}$ value $<1500 \mu \mathrm{g} / \mathrm{mL}$. Whilst the methanolic and ethyl acetate extracts also significantly inhibited Caco2 cell proliferation, $\mathrm{IC}_{50}$ values could not be determined as the \% inhibition of proliferation did not exceed $50 \%$ at any concentration tested.

\section{Cell imaging studies}

The antiproliferative studies presented in this manuscript demonstrate that the methanolic and aqueous T. sericea extracts have profound effects

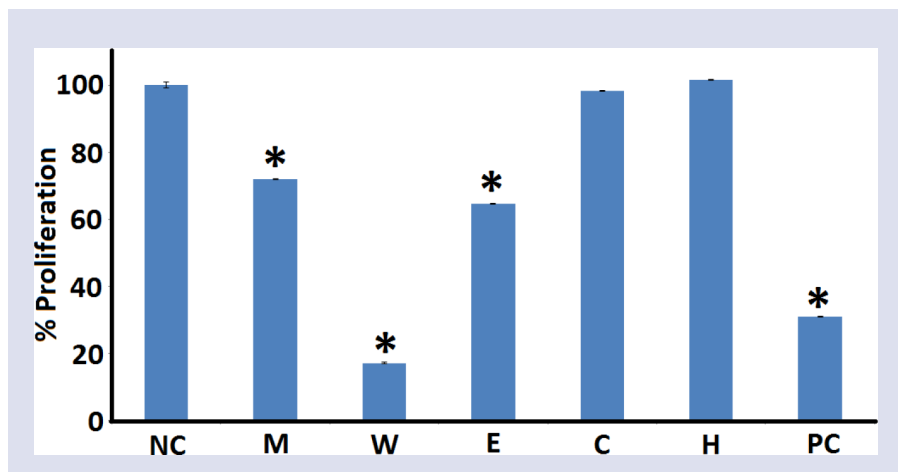

Figure 1: Anti-proliferative activity of the T. sericea extracts and untreated controls against $\mathrm{Caco} 2$ cancer cell lines measured as percentages of the untreated control cells. $\mathrm{NC}=$ untreated control; $\mathrm{M}=$ methanolic $T$. sericea extract; $\mathrm{W}=$ aqueous $T$. sericea extract; $\mathrm{E}=$ ethyl acetate $T$. sericea extract; $\mathrm{C}=$ chloroform $T$. sericea extract; $\mathrm{H}=$ hexane $T$. sericea extract; $\mathrm{PC}=$ cisplatin control $(50 \mu \mathrm{g} / \mathrm{mL})$. Results are expressed as mean percentages \pm SEM of at least triplicate determinations. ${ }^{*}$ indicates results that are significantly different to the untreated control $(p<0.01)$.

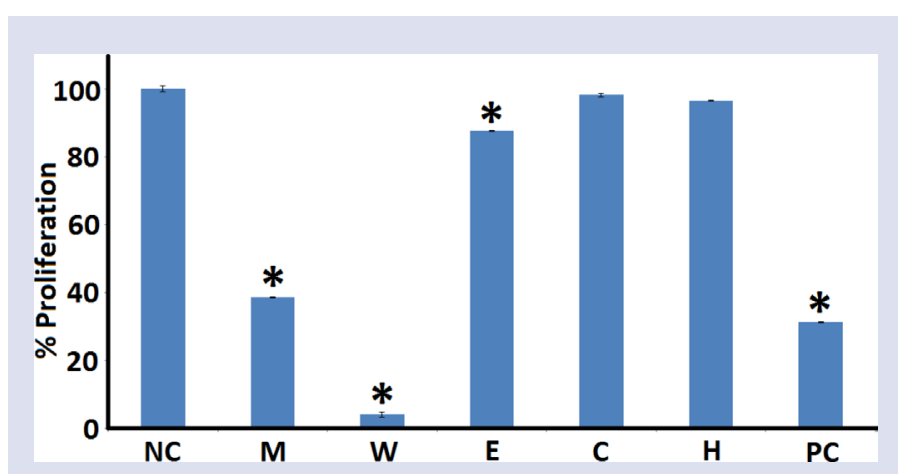

Figure 2: Anti-proliferative activity of the T. sericea extracts and untreated controls against HeLa cancer cell lines measured as percentages of the untreated control cells. NC = untreated control; $\mathrm{M}=$ methanolic T. sericea extract; $\mathrm{W}=$ aqueous $T$. serice $a$ extract; $\mathrm{E}=$ ethyl acetate $T$. sericea extract; $\mathrm{C}=$ chloroform $T$. sericea extract $\mathrm{H}=$ hexane $T$. sericea extract; $\mathrm{PC}=$ cisplatin control $(50 \mu \mathrm{g} / \mathrm{mL})$. Results are expressed as mean percentages \pm SEM of at least triplicate determinations. ${ }^{*}$ indicates results that are significantly different to the untreated control $(p<0.01)$.

Table 2: The IC $C_{50}$ values $(\mu \mathrm{g} / \mathrm{mL})$ of Caco2 colorectal cancer and HeLa cervical cancer cell lines and the $L_{50}$ values $(\mu \mathrm{g} / \mathrm{mL})$ for Artemia franciscana exposed to the $T$. sericea extracts.

\begin{tabular}{cccc}
\hline \multirow{2}{*}{ Extract } & \multicolumn{2}{c}{$\mathrm{IC}_{50}(\mathrm{ug} / \mathrm{mL})$} & $\mathrm{LC}_{50}(\mathrm{ug} / \mathrm{mL})$ \\
\cline { 2 - 3 } & $\mathrm{CaCo} 2$ & HeLa & 1088 \\
$\mathrm{M}$ & $\mathrm{CND}$ & 1358 & 737 \\
$\mathrm{~W}$ & 528 & 120 & $\mathrm{CND}$ \\
$\mathrm{E}$ & $\mathrm{CND}$ & $\mathrm{CND}$ & $\mathrm{CND}$ \\
$\mathrm{C}$ & - & - & $\mathrm{CND}$ \\
$\mathrm{H}$ & - & - & $\mathrm{C}$ \\
\hline
\end{tabular}

$\mathrm{M}=$ methanolic T. sericea extract; $\mathrm{W}=$ aqueous T. sericea extract; $\mathrm{E}=$ ethyl acetate T. sericea extract; $\mathrm{C}=$ chloroform T. sericea extract; $\mathrm{H}=$ hexane T. sericea extract; $\mathrm{CND}=$ could not determine as inhibition of proliferation or mortality did not exceed $50 \%$ at any concentration tested; - indicates no inhibition of proliferation was noted at any concentration tested. 
on Caco2 and HeLa cellular proliferation (Figures 1 and 2). These large decreases in cell proliferation compared to the untreated control cells indicated that these extracts may not just inhibit growth by blocking cell cycle progression, but may instead act via cytotoxic/apoptotic mechanisms. However, further studies are required to test this hypothesis and cell imaging studies were undertaken to confirm this finding. The Caco2 cell line was chosen for cell imaging studies as it is a commonly used cell line in similar studies (allowing for comparisons), has well defined cell morphology, has a reasonable doubling time compared with many other cell lines and was responsive to the T. sericea extracts.

The key organelles for comparison between the treated and untreated cells in these studies are the nucleus, cytoplasm, vacuoles and cell membrane, all of which were clearly visible at $20 \mathrm{X}$ optical magnification of the cell in the untreated control cell image (Figure 3a). The outline of the cell is clear, distinct and compact without abnormalities in size and density. Stress granules were not visible at this magnification. These are normally indicators of cellular stress, if it is present. Typical apoptotic phenomena were noted in the morphology of the cells tested against the methanolic (Figure 3b) and aqueous (Figure 3c) extracts when tested at sub-lethal concentrations. These images are consistent with the findings of the cell proliferative assays which showed that both the methanolic and aqueous $T$. sericea extracts strongly inhibited $\mathrm{Caco} 2$ proliferation. This correlates with the morphological characteristics noted in this study. Apoptosis is generally characterised by the presence of an intact membrane, marginalisation of the cytoplasm and chromatin condensation. ${ }^{35}$ These characteristics were clearly visible in the Caco 2 cells treated with the methanolic and aqueous T. sericea extracts (Figure $3 \mathrm{~b}$ and Figure $3 \mathrm{c}$ ). Marginalisation of the cytoplasm of cells undergoing apoptosis also produces an enormously large centrally placed vacuole which is clearly visible in both figures. The presence of stress granules in the visible fields (Figures $3 \mathrm{a}$ and $3 \mathrm{~b}$ ) indicates that the cells are under stress. 'Blebbing' is the appearance of 'spherical bubbles' on the surface of the membrane and is a typical characteristic apparent in apoptotic cells. 'Blebbing' is also seen in cells tested against the methanolic and aqueous T. sericea extracts (Figures $3 \mathrm{a}$ and $3 \mathrm{~b}$ ). These cells also displayed a loss in membrane integrity with no clear outline of the cell visible, extensive chromatin condensation and the presence of numerous vacuoles. Also visible for both treatments were the 'ghosts' of cell where cellular contents are no longer present within cell. The morphological changes observed with both treatments are indicative of the induction of apoptosis.

\section{Quantification of toxicity}

All extracts were initially screened at $2000 \mu \mathrm{g} / \mathrm{mL}$ in the assay (Figure 4). For comparison, the reference toxin potassium dichromate $(1000 \mu \mathrm{g} / \mathrm{mL})$ was also tested in the bioassay. Figure 4 shows the $\%$ mortality induced by each extract and by the control toxin following $24 \mathrm{~h}$ exposure. The potassium dichromate reference toxin was rapid in its onset of mortality, inducing mortality within the first $3 \mathrm{~h}$ of exposure and $100 \%$ mortality was evident following 4-5 h (unpublished results). Similarly, the methanolic and aqueous $T$. sericea extracts displayed $100 \%$ mortality rates at $24 \mathrm{~h}$ and were thus deemed to be toxic. All other extracts induced only low levels of mortality which was not significantly different to the mortality determined for the negative control. These extracts were therefore deemed to be nontoxic.

To further quantify the effect of extract concentration on the induction of mortality, the extracts were serially diluted in artificial seawater to test across a range of concentrations in the Artemia nauplii bioassay. Table 2 shows the $\mathrm{LC}_{50}$ values of the extracts towards $A$. franciscana. No $\mathrm{LC}_{50}$ values are reported for the ethyl acetate, chloroform or hexane T. sericea extracts as less than $50 \%$ mortality was seen for all concentrations tested. Whilst the methanolic extract initially appeared to be toxic in the screening
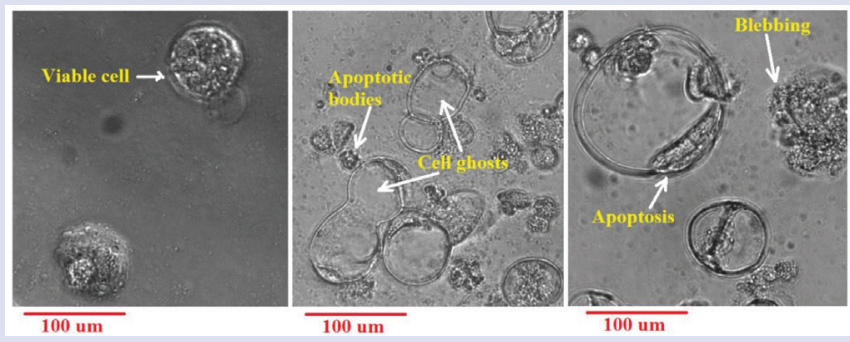

Figure 3: Effects of T. sericea extracts on the morphological characteristics of Caco2 cells: (a) viable $\mathrm{CacO} 2$ cells without exposure to extracts; (b) Caco2 cells exposed to the methanolic T. sericea extract; $\mathrm{Caco} 2$ cells exposed to the aqueous T. sericea extract.

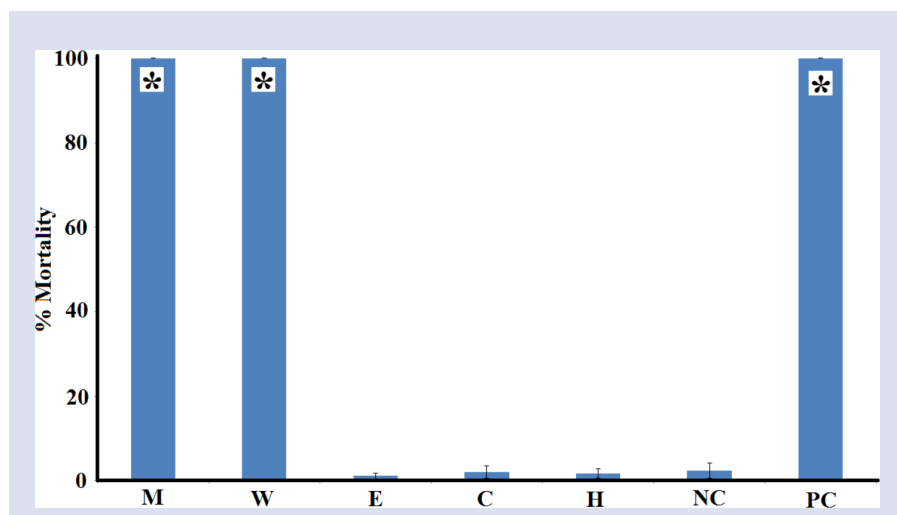

Figure 4: The lethality of the $T$. sericea extracts $(2000 \mu \mathrm{g} / \mathrm{mL})$ and the potassium dichromate control $(1000 \mu \mathrm{g} / \mathrm{mL}$ ) towards Artemia nauplii following $24 \mathrm{~h}$ exposure. $\mathrm{M}=$ methanolic $T$. sericea extract; $\mathrm{W}=$ aqueous $T$. sericea extract; $\mathrm{E}=$ ethyl acetate $T$. sericea extract; $\mathrm{C}=$ chloroform $T$. sericea extract; $\mathrm{H}=$ hexane $T$. sericea extract; $\mathrm{NC}=$ negative control; $\mathrm{PC}=$ positive control $(1000 \mu \mathrm{g} / \mathrm{ml}$ potassium dichromate). All tests were performed in at least triplicate and the results are expressed as mean \pm SEM. * indicates results that are significantly different to the negative control $(p<0.01)$.

study, determination of its $\mathrm{LC}_{50}$ value $(1088 \mu \mathrm{g} / \mathrm{mL})$ demonstrated that it was nontoxic as extracts with an $\mathrm{LC}_{50}>1000 \mu \mathrm{g} / \mathrm{mL}$ towards Artemia nauplii are defined as being nontoxic. ${ }^{34}$ In contrast, an $\mathrm{IC}_{50}$ value of the $737 \mu \mathrm{g} / \mathrm{mL}$ was determined for the aqueous T. sericea leaf extract, indicating moderate toxicity. However, it is noteworthy that Terminalia spp. extract often have very high antioxidant content which may be due to high levels of ascorbic acid. ${ }^{19}$ As high ascorbic acid contents significantly decrease the assay $\mathrm{pH}$ and Artemia nauplii are sensitive to $\mathrm{pH}$ changes, this may be a fallacious result.

\section{DISCUSSION}

Maintenance of the cellular redox state is required for the normal functioning of living systems. This redox maintenance involves a regulated balance between oxidants and antioxidants. Cells use a variety of different antioxidant mechanisms to help maintain this redox state. ${ }^{36,37}$ These cellular defences include enzymatic antioxidants (superoxide dismutase, catalase, thioredoxin, thioredoxin reductase, glutathione peroxidase and glutathione peroxidase) and non-enzymatic antioxidants (glutathione, vitamins $\mathrm{A}, \mathrm{C}$ and $\mathrm{E}$ ). Deregulation of the redox balance has been implicated in numerous diseases including atherosclerosis, diabetes, cirrhosis, ${ }^{16}$ 
autoimmune disease and chronic inflammation, ${ }^{38}$ neurodegeneration ${ }^{16}$ and cancer. ${ }^{36,37}$ An understanding of redox regulation is important in identifying new targets for the development of new drugs for cancer prevention and cancer therapy.

Epidemiological studies have shown that a diet rich in antioxidants is associated with a decreased incidence of chronic diseases. ${ }^{38}$ Individuals with elevated dietary intakes of non-enzymatic antioxidants such as vitamins $\mathrm{A}, \mathrm{C}$ and $\mathrm{E}$ are less likely to suffer many chronic illnesses and some forms of cancer. ${ }^{38,39}$ High antioxidant levels have also been shown to prevent the development of neural degeneration..$^{40}$ Interestingly, the most potent anti-proliferative activity against cancer cells in our study correlated with the highest antioxidant capacity extracts, indicating that the extracts may function via modulation of cellular redox status.

High antioxidant plant extracts may contain many types of phythochemicals, of which phenolic compounds are prevalent. Phenolic compounds are generally strong antioxidants. ${ }^{6}$ Their primary action involves the protection of cell constituents against oxidative damage through the scavenging of free radicals, thereby averting their deleterious effects on nucleic acids, proteins, and lipids in cells. ${ }^{6}$ Phenolics may interact directly with receptors or enzymes involved in signal transduction, ${ }^{7}$ clearly indicating that they play a specific role in human physiology. Therefore, consumption of plant material or extracts with high antioxidant capacities may contribute to reducing oxidative damage via nonenzymatic mechanisms and the scavenging of free radicals. However, studies into the medicinal effects of antioxidants have proved confusing, with some studies showing therapeutic effects, ${ }^{41,42}$ whilst other studies indicate that these antioxidants may themselves be toxic. ${ }^{33,43}$ The effects of antioxidants are dose dependent, with low doses behaving as antioxidants, while high doses themselves induce toxicity through the induction of oxidative stress ${ }^{44}$

Multicellular organisms require a reducing environment for cell proliferation. This is accomplished when there are high reduced glutathione (GSH) levels and low levels of antioxidant proteins such as superoxide dismutase (SOD), glutathione peroxidise (GPx) and catalase. ${ }^{45,46}$ The redox environment of the cell also plays a significant role in cell differentiation. In contrast to proliferation, differentiation requires an oxidising environment. Low levels of antioxidants induce cell proliferation whilst high levels inhibit it. ${ }^{47}$ Therefore, proliferation favours a reducing environment whilst differentiation requires an oxidizing environment. ${ }^{48,49}$ ROS may also play an important physiological role as secondary messengers. ${ }^{50}$ and in the maintenance of cellular redox balance. Consumption of phenolic antioxidants may help to reduce the oxidative stress of the cell, and of the whole organism.

The antiproliferative efficacy of T. sericea leaf extracts was examined against two cancer cell lines in vitro; $\mathrm{CaCo}-2$ (colorectal) and $\mathrm{HeLa}$ (cervical). Interestingly, the observed antioxidant activity was related to the antiproliferative activity of the cancer cells. All of the extracts with high antioxidant content demonstrated antiproliferative activity against both cancer cell lines. Conversely, extracts with low antioxidant capacity lacked antiproliferative activity. A previous study on the antioxidant activity of fresh apples reported a similar relationship between antioxidant activity and antiproliferative activity against Caco 2 cells. ${ }^{51}$ It was suggested that the antiproliferative activity was due to the combination of phenolic acids and flavonoids. ${ }^{51}$ This correlates with the results observed in the qualitative phytochemical analysis of this report. Phenolic and flavonoid compounds were observed to be present in high levels in all of the extracts that displayed antiproliferative activity, and in much lower levels in the extracts that did not inhibit cellular proliferation. Flavonoids are believed to protect cells from disease by shielding lipids, proteins and DNA from oxidative damage. ${ }^{52}$ Previous in vitro bioactivity studies of flavonoids have demonstrated anti-inflammatory, antioxidant, and anti- cancer activity. ${ }^{52}$ Individual extract components responsible for the antiproliferative activity of the $T$ sericea leaf extracts were not identified in the current study.

Whilst the use of high levels of antioxidants may be an attractive option in the prevention and treatment some cancers, oxidative stress is not the sole factor in the development and progression of cancer. Genetic factors, dietary habits and environmental factors may all contribute to cancer development. Furthermore, even in oxidative stress induced cancers, dietary antioxidants are of limited value as it is difficult to supply enough of the beneficial antioxidants directly in the food to function effectively as chemoprotectants and/or chemotherapeutics. Instead, high antioxidant extracts are required to obtain a high enough dosage to be effective. Despite this, numerous studies have reported the beneficial effects of using high levels of phytochemical antioxidants in cancer prevention and treatment. Therefore, high antioxidant plant extracts such as the aqueous $T$ sericea leaf extract examined in this report may also prove to be useful anticancer agents.

The findings reported here also demonstrate that the majority of the T sericea leaf extracts were nontoxic towards Artemia franciscana nauplii. Of the extracts tested, only the aqueous extract displayed an $\mathrm{LC}_{50}$ value $<1000 \mu \mathrm{g} / \mathrm{mL}$. This extract was also determined to have a very high antioxidant capacity (equivalent to $340 \mu \mathrm{g}$ ascorbic acid per $\mathrm{g}$ of dried $T$ sericea leaf extracted). As Artemia nauplii are susceptible to $\mathrm{pH}$ changes ${ }^{34}$ such as those seen with the addition of ascorbic acid (the most prevalent antioxidant in the leaves), it is possible the mortality induced by these extracts is due to their high ascorbic acid contents. All other extracts examined in this study were nontoxic, although further studies using human cell lines are required to verify the safety of these extracts for therapeutic use.

\section{CONCLUSION}

The results of this study demonstrate the potential of the aqueous and methanolic T. sericea leaf extracts to block proliferation of some cancer cells. The low toxicity of the extracts further indicates their potential in the treatment and prevention of some cancers. Purification and identification of the bioactive components is needed to examine the mechanisms of action of these agents.

\section{ACKNOWLEDGEMENT}

The authors are grateful to Professor Sandy van Vuuren of Witwatersrand University and Andrew Hankey of the Walter Sisulu Botanical Gardens, Johannesburg, South Africa for supplying and identifying the T. sericea leaves used in this study. Financial support for this work was provided by the Environmental Futures Research Institute, Griffith University.

\section{CONFLICTS OF INTEREST}

The authors report no conflicts of interest.

\section{ABBREVIATION USED}

DMSO: Dimethyl sulfoxide; $\mathbf{L C}_{50}$ : The concentration required to achieve $50 \%$ mortality; IC $_{50}$ : The concentration required to achieve $50 \%$ effect.

\section{REFERENCES}

1. Potter JD. Cancer prevention: Epidemiology and experiment. Cancer Lett. 1997; 114(1-2):7-9.

2. Hertog MG, Bueno-de-Mesquita HB, Fehily AM, Sweetnam PM, Elwood PC, Kromhout D. Fruit and vegetable consumption and cancer mortality in the caerphilly study. Cancer Epidemiol Biomarkers Prev. 1996;5(9):673-7.

3. Vita JA. Polyphenols and cardiovascular disease: Effects on endothelial and platelet function. Am J Clin Nutrit. 2005;81(1):292S-7S.

4. Youdim KA, Spencer JPE, Schroeter H, Rice-Evans CA. Dietary flavonoids as 
potential neuroprotectans. Biol Chem. 2002;383(3-4):503-19.

5. Tsuda T, Horio F, Uchida K, Aoki H, Osawa T. Dietary cyanidin 3-O-b- D-glucoside-rich purple corn colour prevents obesity and ameliorates hyperglycemia in mice. J Nutr. 2003;133(7):2125-30

6. Rice-Evans C, Miller N, Paganga. Antioxidant properties of phenolic compound. Trends Plant Sci. 1997;2(4):152-9.

7. Moskaug JO, Carlsen H, Myhrstad MC, Blomhoff R. Polyphenols and glutathione synthesis regulation. Am J Clin Nutr. 2005;81(1):277S-83S

8. Brown NS, Bicknell R. Hypoxia and oxidative stress in breast cancer. Oxidative stress: its effects on the growth, metastatic potential and response to therapy of breast cancer. Breast Cancer Research. 2001;3(5):323-27.

9. Tome ME, Baker AF, Powis G, Payne CM, Briehl MM. Catalase-overexpressing thymocytes are resistant to glucocorticoid-induced apoptosis and exhibit increased net tumor growth. Cancer Res. 2001;61(6):2766-73.

10. Cock IE. Problems of reproducibility and efficacy of bioassays using crude extracts, with reference to Aloe vera. Pharmacognosy Communications. 2011;1(1):52-62

11. Rahman A, Shahabuddin M, Hadi SM, Parish J. Complexes involving quercetin, DNA and $\mathrm{Cu}(\mathrm{II})$. Carcinogenesis. 1990;11(11):2001-3.

12. Singh S, Farhan AS, Ahmad A, Khan NU, Hadi SM. Oxidative DNA damage by capsaicin and dihydrocapsaicin in the presence of $\mathrm{Cu}(\mathrm{II})$, Cancer Letters. $2001 ; 169(2): 139-46$

13. Lastra CA, Villegas I. Resveratrol as an antioxidant and pro-oxidant agent: Mechanisms and clinical implications. Biochemical Society Transactions. 2007:35:1156-60.

14. Wu CC, Lu YH, Wei BL, Yang SC, Won SJ, Lin CN. Phloroglucinols with prooxidant activity from Garcinia subelliptica. Journal of Natural Products. 2008;71(2):246-50.

15. Joel LS. The dual roles of nutrients as antioxidants and pro-oxidants: Their effects of tumor cell growth. In proceeding of the "Prooxidant Effects of Antioxidant Vitamins" experimental biology meeting, Atlanta, GA, Edited by Herbert V, American Society of Nutrition. 1995; Bethesda, MD: 1221-6.

16. Halliwell B. Vitamin C: Antioxidant or pro-oxidant in vivo? Free Radical Research. 1996;25(5):439-54

17. Herbert $V$, Shaw $S$, Jayatileke $E$. Vitamin $C$ driven free radicals generation from iron. Journal of Nutrition. 1996;126(4s):1213-20.

18. Samuni A, Aronovitch J, Godinger D, Chevion M, Czapsk G. On the cytotoxicity of vitamin $\mathrm{C}$ and metal ions. A site-specific Fenton mechanism. European Journal of Biochemistry. 1983;137:119-24

19. Cock IE. The medicinal properties and phytochemistry of plants of the genus Terminalia (Combretaceae). Inflammopharmacology. 2015;23(5);203-29. DOI: 10.1007/s10787-015-0246-z

20. Sandhya T, Lathika KM, Pandey BN, Mishra KP. Potential of traditional Ayurvedic formulation, triphala, as a novel anticancer drug. Cancer Letters. 2006;231(2):206-14.

21. Kaur S, Michael H, Arora S, Härkönen PL, Kumar S. The in vitro cytotoxic and apoptotic activity of Triphala: An Indian herbal drug. Journal of Ethnopharmacology. 2005;97(1):15-20.

22. Shi Y, Sahu RP, Srivastava SK. Triphala inhibits both in vitro and in vivo xenograft growth of pancreatic tumor cells by inducing apoptosis. BMC Cancer. 2008;8(1):294

23. SandhyaT, Mishra KP. Cytotoxic response of breast cancer cell lines, MCF-7 and T $47 \mathrm{D}$ to triphala and its modification by antioxidants. Cancer Letters. 2006; 238(2):304-13.

24. Pinmai K, Chunlaratthanabhorn S, Ngamkitidechakul C, Soonthornchareon N, Hahnvajanawong C. Synergistic growth inhibitory effects of Phyllanthus emblica and Terminalia bellerica extracts with conventional cytotoxic agents: Doxorubicin and cisplatin against human hepatocellular carcinoma and lung cancer cells. World Journal of Gastroenterology. 2008;14(10):1491-7.

25. Tan AC, Konczak I, Ramzan I, Sze DMY. Potential antioxidant, antiinflammatory, and proapoptotic anticancer activities of Kakadu plum and Illawarra plum polyphenolic fractions. Nutrition and Cancer 2011;63(7):1074-84.

26. Courtney R, Sirdaarta J, White A, Cock IE. Inhibition of Caco-2 and HeLa proliferation by Terminalia carpentariae C.T.White and Terminalia grandiflora Benth. Extracts: Identification of triterpenoid components. Pharmacognosy Journal. 2017;9(2):175-84. DOI: 10.5530/pj.2017.2.29

27. Kalt FR, Cock IE. GC-MS analysis of bioactive Petalostigma extracts: Toxicity, antibacterial and antiviral activities. Pharmacognosy Magazine. 2014;10(7):S37-S48. DOI: $10.4103 / 0973-1296.127338$

28. Vesoul J, Cock IE. An examination of the medicinal potential of Pittosporum phylloraeoides: Toxicity, antibacterial and antifungal activities. Pharmacognosy Communications 2011;1(2):8-17.

29. Arkhipov A, Sirdaarta J, Rayan P, McDonnell PA, Cock IE. An examination of the antibacterial, antifungal, anti-Giardial and anticancer properties of Kigelia africana fruit extracts. Pharmacognosy Communications. 2014;4(3):62-76. DOI: 10.5530/pc. 2014.3 .7

30. Jamieson N, Sirdaarta J, Cock IE. The anti-proliferative properties of Australian plants with high antioxidant capacities against cancer cell lines. Pharmacognosy Communications. 2014;4(4):71-82. DOI: 10.5530/pc.2014.4.8

31. Boyer $\mathrm{H}$, Cock IE. Evaluation of the potential of Macademia integriflora extracts as antibacterial food agents. Pharmacognosy Communications. 2013;3(3):53-62. DOI: $10.5530 / p c .2013 .3 .10$

32. Cock IE, Ruebhart, DR. Assessment of the toxicity of selected Australian native plant extracts using the Artemia franciscana nauplii bioassay. The Internet Journal of Toxicology. 2008;5(2):2

33. Sirdaarta J, Cock IE. Vitamin E and Trolox ${ }^{\mathrm{TM}}$ reduce toxicity of Aloe barbadensis Miller juice in Artemia franciscana nauplii but individually are toxic at high concentrations. The Internet Journal of Toxicology. 2008:5:1.

34. Ruebhart DR, Wickramasinghe W, Cock IE. Protective efficacy of the antioxidants vitamin $\mathrm{E}$ and Trolox against Microcystis aeruginosa and microcystin-LR in Artemia franciscana nauplii. Journal of Toxicology and Environmental Health Part A. 2009;72(24):1567-75.

35. Chang Z, Xing J, Yu X. Curcumin induces osteosarcoma MG63 cells apoptosis via ROS/Cyto-C/Caspase-3 pathway. Tumor Biology. 2014; 35(1):753-8

36. Mohanty S, Cock IE. The chemotherapeutic potential of Terminalia ferdinandiana: Phytochemistry and bioactivity. Pharmacognosy Reviews. 2012;6(11):29-36 DOI: 10.4103/0973-7847.95855

37. Cock IE. The phytochemistry and chemotherapeutic potential of Tasmannia lanceolata (Tasmanian pepper): A review. Pharmacognosy Communications. 2013:3(4):13-25. DOI: 10.5530/pc.2013.4.3

38. Potter JD. Cancer prevention: Epidemiology and experiment. Cancer Letters. $1997 ; 114(1-2): 7-9$

39. Hertog MG, Bueno-de-Mesquita HB, Fehily AM, Sweetnam PM, Elwood PC Kromhout D. Fruit and vegetable consumption and cancer mortality in the caerphilly study. Cancer Epidemiology, Biomarkers and Prevention. 1996;5(9): 673-7.

40. Youdim KA, Spencer JP, Schroeter H, Rice-Evans CA. Dietary flavonoids as potential neuroprotectans. Biol Chem. 2002;383(3-4):503-19.

41. Coskun S, Gönül B, Güzel NA, Balabanli B. The effects of vitamin C supplementation on oxidative stress and antioxidant content in the brains of chronically exercised rats. Mol Cell Biochem. 2005;280(1):135-38.

42. Tafazoli S, Wright JS, O'Brien PJ. Pro-oxidant and antioxidant activity of vitamin E analogues and troglitazone. Chem Res Toxicol. 2005;18(10):1567-74.

43. Driver C, Georgeou A. Variable effects of vitamin E on Drosophilia longevity. Biogerontol. 2003;4(2):91-95.

44. Miller ER, Pastor-Barriuso R, Dalal D, Riemersma RA. 2005. Meta-analysis: high dosage vitamin E supplementation may increase all-cause mortality. Annals of Internal Medicine. 2005;142(1):37-46

45. Sohal RS, Arnold L, Orr WC. Effect of age on superoxide dismutase, catalase glutathione reductase, inorganic peroxides, TBA-reactive material, GSH/GSSG $\mathrm{NADPH} / \mathrm{NADP}^{+}$and NADH/NAD ${ }^{+}$in Drosophila melanogaster. Mechanisms of Ageing and Development. 1990;56(3):223-35.

46. Allen RG, Venkatraj VS. 1992. Oxidants and antioxidants in development and differentiation. J Nutr. 1992;122(3S):631-5.

47. Yang GY, Wang ZY, Kim S, Liao J, Seril DN, Chen X, Smith TJ, Yang CS Characterization of early pulmonary hyperproliferation, tumor progression and inhibition by black tea in a 4- (methylnitrosamino)-1-(3-pyridyl)-1-butanone (NNK)-induced lung tumorigenesis model with A/J mice. Cancer Res. 1997;57(10):1889-94.

48. Burdon $\mathrm{RH}$. Superoxide and hydrogen peroxide in relation to mammalian cell proliferation. Free Radical Biology and Medicine. 1995;18(4):775-94.

49. Alaluf S, Muir-Howie H, Hu HL, Evans A, Green MR. Atmospheric oxygen accelerates the induction of a post-mitotic phenotype in human dermal fibroblasts: the key protective role of glutathione. Differentiation. 2000;66(2):147-55.

50. Lowenstein CJ, Snyder SH. Nitric acid, a novel biological messenger. Cell 1992; 70(5):705-07.

51. Eberhardt, MV, Lee CY, Liu RH. Nutrition: Antioxidant activity of fresh apples Nature. 2000;405(6789):903-04.

52. Chen AY, Chen YC. A review of the dietary flavonoid, kaempferol on human health and cancer prevention. Food Chemistry. 2013;138(4):2099-107.

Cite this article: Gu B, Shalom J, Cock IE. Anti Proliferative Properties of Terminalia Sericea Burch. Ex Dc Leaf Extracts Against Caco2 and HeLa Cancer Cell Lines. Pharmacog J. 2018;10(3):408-15. 
GRAPHICAL ABSTRACT

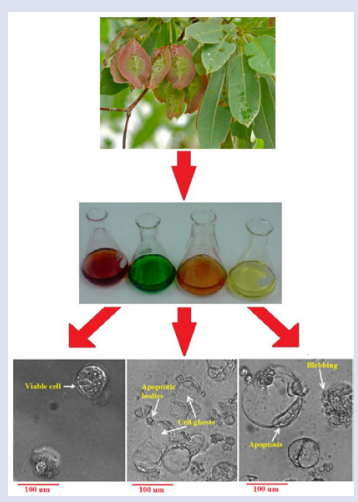

\section{ABOUT AUTHORS}

SUMMARY

- Terminalia sericea methanolic and aqueous T. sericea leaf extracts were potent inhibitors of Caco2 and HeLa cancer cell proliferation ( $\mathrm{IC}_{50}$ values $\left.120-1400 \mu \mathrm{g} / \mathrm{mL}\right)$.

- $\quad$ The antiproliferative activity corresponded correlated with the antioxidant capacities.

- The aqueous T. sericea leaf extract was particularly effective, with $\mathrm{IC}_{50}$ values of 528 and $120 \mu \mathrm{g} / \mathrm{mL}$ against Caco2 and HeLa cells respectively.

- The methanolic extract also displayed good, antiproliferative activity against HeLa cells, with an $I_{50}$ of $1358 \mu \mathrm{g} / \mathrm{mL}$.

- Cell imaging studies indicated that the antiproliferative activity was due to apoptosis.

- The T. sericea extracts were either nontoxic or of only low toxicity in the Artemia franciscana bioassay.

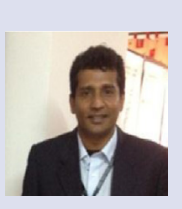

Joseph Sirdaarta is currently a PhD student at School of Natural Sciences, Griffith University, Australia under the supervision of Dr lan Cock. His research project examinines the anticancer properties of a variety of Australian native plants. He has also undertaken studies into antibacterial, antiprotozoal and anti-inflammatory properties of natural and traditional medicines, resulting in over 20 publications and 15 conference presentations.

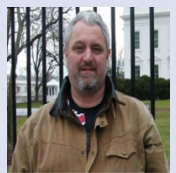

Dr lan Cock leads a research team in the Environmental Futures Research Institute and the School of Natural Sciences at Griffith University, Australia. His research involves bioactivity and phytochemical studies into a variety of plant species of both Australian and international origin, including Aloe vera, South Asian and South American tropical fruits, as well as Australia plants including Scaevola spinescens, Pittosporum phylliraeoides, Terminalia ferdinandiana (Kakadu plum), Australian Acacias, Syzygiums, Petalostigmas and Xanthorrhoea johnsonii (grass trees). This range of projects has resulted in nearly 200 publications in a variety of peer reviewed journals. 